\title{
Şerh ve Otorite İlişkisi: XVII. Yüzyıla Ait Bir Şerhin Analizi
}

\section{Yunus ÖZTÜRK•}

Relation of Sharh and Authority: Analysis of a Sharh of the 17 th Century

Citation/@: Öztürk, Yunus, (2017). Relation of Sharh and Authority: Analysis of a Sharh of the 17th Century, Milel ve Nihal, 14 (1), 288-311.

Abstract: Authority as a modern concept has various types. It is also thought the authority has a more political meaning. Besides there is also a fact that texts and writters/authors have played directive, influential and determinative roles in society. In this respect, we can say that texts and writters/authors are indirectly spiritual / intellectual authority within society. The aim of this study is to trace the relation of textual and paradigmatic authority in the 17th century in the Ottoman Empire over a certain work and its sharh.

Key Words: Text and authority, sharh, Nasafi, Karabas, al-'Aqaid.

Arş. Gör., Hitit Üniversitesi, İlahiyat Fakültesi, Kelam Anabilim Dalı [ynsztrk52@gmail.com] 
Atıf/C): Öztürk, Yunus, (2017). Şerh ve Otorite İlişkisi: XVII. Yüzyıla Ait Bir Şerhin Analizi, Milel ve Nihal, 14 (1), 287-311.

Öz: Modern bir kavram olan otoritenin farklı türleri bulunmaktadır. Otoritenin daha çok siyasi bir anlam taşındığı da düşünülmektedir. Ancak yazılı metinler ve müelliflerin toplumsal alanda yönlendirici, etkileyici ve belirleyici oldukları da bir vakıadır. Bu itibarla metin ve müelliflerin de dolaylı surette toplum içinde manevi/entelektüel bir otoritesinin olduğu söyleyebiliriz. Bu çalışma belirli bir eser ve eserin şerhi üzerinden XVII. Yy. Osmanlısı'nda metinsel ve paradigmatik otorite ilişkisinin izini sürmeyi amaçlamaktadır.

Anahtar Kelimeler: Metin ve otorite, şerh, Nesefi, Karabaş, akâid.

\section{Giriş}

İslâmî gelenek içerisinde temel inanç ilkeleri ve bunlarla ilgili hususları muhtasar olarak ele alan akâid risâleleri bulunmaktadır. Akâid metinleri arasında Nesefî'nin akâidi'nin ise oldukça önemli bir yeri vardır. Eserin önemi kelam konularını oldukça muhtasar ve sarih bir şekilde ele almasından kaynaklanmaktadır. Kendi dönemini aşıp uzun yıllar okunan bir metin olması da, Nesefî'nin akâidi'nin etkisini vurgulayan ve değerini artıran hususlardandır. Kendisini şerh eden şarihler dikkate alındığında, Nesefî'nin eserinin kendinden sonraki süreçte şerh edilen en önemli metinlerden olduğu söylenebilir. Mütekellim ve mutasavvıflar tarafından ayrı ayrı şerh edilen metnin en önemli şerhi, et-Taftâzâni'nin şerhidir. Bu sebepledir ki et-Taftâzânî'nin şerhi de dikkat çekmiş ve üzerine hâşiyeler yazılmıştır. Bu bağlamda et-Taftâzânî'nin şerhi'nin de Nesefî'nin akâidi'ni öne çıkaran hususlardan olduğu ifade edilebilir. ${ }^{1}$

\footnotetext{
${ }^{1}$ Metnu'l-Akâid ve Şerhu'l-Akâid hakkında detaylı bilgi için bkz. Taftazânî, Kelam İlmi ve İslâm Akâidi (Şerhu'l-Akâid), Haz: Süleyman Uludă̆, Dergah Yay., 5. Bsk., İstanbul 2010, ss. 50-73; Yusuf Şevki Yavuz, "Akâidu'n-Nesefî", DİA, y1l: 1989, c. II, ss. 217-219; Abdullah Dinç, “Beyânu'l-Mezâhib Adlı Eseri Bağlamında Ömer Nesefi'nin Mezhepleri Tasnifi", Yayınlanmamış Yüksek Lisans Tezi, Kahramanmaraş Sütçü İmam Üniversitesi Sosyal Bilimler Enstitüsü, Kahramanmaraş 2012, s. 18; Bir metnin şerh için tercih edilmesi, şerh ve haşiyenin muhtemel anlamları vb. hususlar için önemli bir çalışma için ayrıca bkz. İsmail Kara, İlim Bilmez Tarih Hatırlamaz- Şerh ve Haşiye Meselesine Dair Birkaç Not, Dergah Yay., 2. Bsk., İstanbul 2013, ss. 19-103.
} 
Makalenin ana konusu, Nesefí'nin şerhleri ve haşiyeleri olmaktan öte, XVII. yy'da Osmanlı Devleti'nde Kadızadeliler ve Sivasîler çekişmesinin siyasi ve sosyo-politik sonuçlarını tecrübe etmiş, ${ }^{2}$ Halvetî tarikatının önemli sûfîlerinden Ali el-Atvel yani Karabaş-1 Velî’nin Şerhu akâidi'n-Nesefî adlı eserindeki değerlendirmeleridir. ${ }^{3}$ $\mathrm{Bu}$ değerlendirmelerin bizim için taşıdığı anlam, iki geleneğin karşılaşması ve sûfî geleneğin kelâmî geleneği okuma ve kendine mal etme çabasında yatmaktadır.

Şerh türü bir telif olması itibariyle Karabaş'ın şerhinin hususiyetleri, dikkat çeken değişim ve dönüşümler, şârihin açıklamaları metnin ait olduğu anlam dünyasıyla mukayeseli bir şekilde tahlil edilecektir. Şârihin özellikle varlık ve bilgi konusundaki yaklaşımları ele alınacaktır. Zira kendisine salt bir meşruiyet zemini aramaktan öte belirli bir dönemden sonra hakikat arayışına evrilen tasavvuf ${ }^{4}$ ile bu arayışı nazari anlamda temsil eden Kelam geleneğinin metin-şerh ilişkisinde buluşturulduğuna şahit olacağız. ${ }^{5} \mathrm{Bu}$ ise bizi zorunlu olarak varlık ve bilgi hakkındaki değerlendirmeler üzerinden mukayeseli bir okumaya yöneltmektedir. Hakikat araştırması iddiasındaki iki geleneğin temel dayanakları ontolojik ve

${ }^{2}$ Kadızadeliler ve Sivasiler'in tartışma konuları için bkz. Kâtip Çelebi, Mîzânü'lhak fì ihtiyâri'l-ahak, Haz: Orhan Şaik Gökyay, MEB Yay., İstanbul 1993, ss. 14-110; Karabaş'ın XVII. yy olaylarındaki durumu hakkında detaylı bilgi için bkz. Kerim Kara, "Karabaş Velî Hayatı - Eserleri ve Fikirleri", Marmara Üniversitesi Sosyal Bilimler Enstitüsü, Doktora Tezi, İstanbul 2002, ss. 13-33. (Bu eser, diğer dipnotlarda Kerim Kara, "Karabaş Velî Hayatı - Eserleri ve Fikirleri”, şeklinde gösterilecektir.) Fıkıh- Tasavvuf ilişkisi bağlamında "fakılar ve sofular" hakkında ayrıca bkz. Ferhat Koca, "Osmanlılar Dönemi Fıkıh-Tasavvuf İlişkisi: Fakılar ile Sofular Mücadelesinin Tarihi Serüveni", Gazi Üniversitesi Çorum İlahiyat Fakültesi Dergisi, 2002/1, cilt: I, say1: 1, ss. 73-131.

${ }^{3}$ Karabaş'ın hayatı, eserleri ve tasavvufi görüşleri için bkz. Kerim Kara, “Karabaş Velî Hayatı - Eserleri ve Fikirleri", ss. 34-376.

${ }^{4}$ Tasavvufun söz konusu meşruiyet çabasına ayrılan müstakil bir çalışma için bkz. Ekrem Demirli, “Zâhiri İlimlerin Otoritesi Karşısında Tasavvuf'un Meşruiyet Arayışı”, İstanbul Üniversitesi İlahiyat Fakültesi Dergisi, sayı: 15, ss. 219-245.

${ }^{5}$ Kelam, usûl-i fıkıh ve tasavvuf gelenekleri arasındaki ilişkiye dair değerlendirmeler için bkz. Ferhat Koca, “Birleşen ve Ayrışan Yönleriyle Usûl-i Fıkhın Kelâm, Tasavvuf ve İslâm Felsefesi İle Olan İlişkisi", İslâmî İlimlerde Metodoloji- VI ,İslâm Düşüncesinin Kurucu Unsurları: Usûl-i Fıkıh, Kelâm, Tasavvuf ve İslâm Felsefesi, / Editörler: İlyas Çelebi, Mehmet Bulgen, 1. Bs. İstanbul: Ensar Neşriyat, 2016, ss. 296-315. 
epistemolojik olduğundan, metinsel otorite olgusunun tespit ve açıklaması da varlık ve bilgi konularını öncelemektedir. Sonuç olarak da Karabaş'ın şerhi hakkında özellikle metin-şerh ilişkisi üzerinden bütüncül bir değerlendirmeye ulaşılmaya gayret gösterilecektir. ${ }^{6}$

Şerh literatürünü eskiyi tekrar, tutuculuk, duraklama vb. nitelemelerle tanımlayan kanaatler bulunmaktadır.7 Ancak bir metnin şerh için tercih edilmesi, şerh edenin ait olduğu gelenek vb. metnin, yazarın ve şârihin şerhte taşıdığı anlamlar üzerine düşünüldüğünde, bir tekrar olmaktan öte yeni bir telif ve inşa olduğu; metne ait problemleri çözüme kavuşturup yeni açılımlar sağladığı göz ardı edilmemelidir. ${ }^{8}$

\section{Hayatı ve Eserleri}

Karabaş-1 Veli şeklinde meşhur olan sûfî, Alaeddin Ali, ${ }^{9}$ Ali el-Atvel, ${ }^{10}$ e-Hac Ali Efendi, el-Hâc Ali el-Üsküdârîn ${ }^{11}$ vb. şekillerde zikredilir. $\mathrm{Bu}$ isimlendirmelerden bazısı kendi kullanımı, bazısı ise başka

${ }^{6}$ Şerhin tamamının bahsettiğimiz anlamda ele alınması makale sınırlarını aşacağından makalede, Karabaş'ın varlık ve bilgi konusundaki değerlendirmeleri üzerinde yoğunlaşılacaktır. Bunun dışında ise sadece bütüncül bir değerlendirme adına şerhte yer alan birkaç açıklamaya yer verilecektir.

${ }^{7} \mathrm{Bu}$ değerlendirmelerin görüldüğü bazı yorum ve tahliller için bkz. Louis Gardet ve Georges Anawati, İslam Teolojisine Giriş: Karşılaştırmalı Teoloji Denemesi, çev.: Ahmet Arslan, Ayrıntı Yay., İstanbul 2015, ss. 117-119; Hasan Mahmûd eş-Şâfiî, Kelam'a Giriş, çev.: Süleyman Akkuş, Değişim Yay., İstanbul 2009, ss. 127-128; Macit Fahri ,İslam Felsefesi Tarihi, çe.: Kasım Turhan, Şa-to Yay., İstanbul 2008, ss. 364-367; İrfan Abdülhamid, İslam'da İtikadi Mezhepler ve Akaid Esasları, çev.: Mustafa Saim Yeprem, Türkiye Diyanet Vakfı Yay., Ankara 2011, s. 159.

${ }^{8}$ Bu konuya ayrılmış hususi ve önemli bir çalışma için bkz. İsmail Kara, İlim Bilmez Tarih Hatırlamaz, ss. 14-103.

${ }^{9}$ Ahmet Cahid Haksever, Çorum Tarihi ve Kültüründe Tasavøuf Geleneğii, Çorum Belediyesi Kültür Yay., Çorum 2009, s. 82.

10 Alaeddin Atvel b. Mehmed Karabaş Velî, Şerhu akâidi'n-Nesefiye bi-lisân ettahkîk, İstanbul Büyükşehir Belediyesi, Osman Ergin Kitaplığı, OE_Yz_1189, vr. 35/a; Alaeddin Atvel b. Mehmed Karabaş Velî, Şerhu akâidi'n-Nesefiye bi-lisân ettahkîk, İstanbul Büyükşehir Belediyesi, Osman Ergin Kitaplığı, OE_Yz_0476, vr. 25/b.

${ }^{11}$ Karabaş Velî Alî b. Muhammed Kastamonulu (öl.1097/1685), Şerhü Akâidin-Nesefîye, Bursa İnebey Yazma Eser Kütüphanesi, Orhan Camii Bölümü, nr. 613/3, vr. 100/a. 
müelliflerin kullanımlarında görülmektedir. Bunlar dışında el-Halveti, el-Kastamonî, er-Rûmî, Çömez Kadı vb. isimlerin de nisbet edildiği belirtilmektedir. ${ }^{12}$

Ailesi hakkında detaylı bilgi sahibi olmamakla birlikte baba tarafından "seyyid" olduğu belirtilen Ali el-Atvel'in, kaynakların çoğunun ittifakı üzere, h. 1020/ m. 1611 yılında Arapgir'de doğduğu söylenmektedir. ${ }^{13}$ Çankırı, Kastamonu, İstanbul gibi farklı şehirlerde yaşayan Karabaş, merhum Kerim Kara'nın belirttiği üzere önemli bir tahsil hayatı geçirmiştir. İsmâil Çorûmî'ye intisap edip tasavvufa yönelmiştir. Şeyhinin vefatının akabinde İstanbul'a gelen Veli, Rum Mehmed Paşa Camii, Valide Atîk Zaviyesi'nde irşad faaliyetlerinde bulunmuş; ancak h. 1090/ m. 1679-80 tarihinde Osmanlı döneminin önemli kelamcılarından Beyazizâde'nin hüccetinin de etkisiyle Limni Adası'na sürgün edilmiştir. Sürgün sebebi hakkında çeşitli rivayetler bulunmaktadır. Bunlar arasında vaazında kullandığı ifadeler, IV. Mehmed'i ağır bir dille eleştirmesi vb. gerekçeler nakledilmektedir.

Gerek Osmanlı'nın gerekse 17. yy'ın en önemli sûfîlerinden olan Niyazi Mısrî ile muasır olan Karabaş, Limni'ye sürgün edildiğinde Mısri de Ada'da sürgündeydi. Yapılan çalışmalardan aralarındaki ilişkilerde Karabaş cihetinden olumlu, Mısrî cihetinden ise olumsuz ve sert bir havanın hakim olduğu anlaşılmaktadır. Affedilmesini takiben Üsküdar'a dönen Karabaş, bir dönem Hac yolculuğuna çıar ve kerametinin de görüldüğü nakledilen dönüş yolunda Kahire yakınlarında h. 1097 yılında vefat eder. Hasan ve Hüseyin

\footnotetext{
${ }^{12}$ Detaylı bilgi için bkz. Kerim Kara, "Karabaş Velî Hayatı - Eserleri ve Fikirleri"., ss. 35-37; Fatih Keskin "Ali el-Atvel Karabaş Velî ve Rislâletü'd-Deverân'ı", Selçuk Üniversitesi Sosyal Bilimler Enstitüsü, (Yayınlanmamış Yüksek Lisans Tezi), Konya 2004, s. 14; Bu eser daha sonraki dipnotlarda Fatih Keskin "Ali el-Atvel Karabaş Velî ve Rislâletü'd-Deverân'1" şeklinde gösterilecektir. Kerim Kara, “Karabaş Veli", DIA, y1l: 2001, c. XXIV, ss. 369; Cemal Kurnaz-Mustafa Tatc1, "Karabaş-1 Velî (ö. 1097/1686)", Tasavouf İmi ve Akademik Araştırmalar Dergisi, sy. 6, Ankara 2001, ss. 35-37.

${ }^{13}$ Kerim Kara, "Karabaş Velî Hayatı - Eserleri ve Fikirleri", ss. 37-38; Fatih Keskin "Ali el-Atvel Karabaş Velî ve Rislâletü'd-Deverân'1", ss. 15-16.
} 
Çelebi, Mustafa el-Ma'nevî isimli oğulları vardır. Oğlu Mustafa Karabaş'ın Şerhu Akâidi'n-Nesefî adlı eserini Lübbü'l-akâid ya da Cevâhiru'l-akâid ismiyle Osmanlıca'ya tercüme etmiştir. ${ }^{14}$

Şerhu Akâidi'n-Nesefî,15 Şerhu Fusûsi'l-Hikem (Kâşifu Esrâri'lFusûs), ${ }^{16}$ Câmi'u Esrâri'l-Fusûs, ${ }^{17}$ Mi'yâru't-Tarîka, ${ }^{18}$ Deverân-ı Sufîyye, ${ }^{19}$ Tarikatname, ${ }^{20}$ Esâsü'd-dîn, ${ }^{21}$ Risâle fî̀ Beyânı Usûl'i Erbaa,,22

${ }^{14}$ Mustafa el-Ma'nevî, Terceme-i Şerhi'l-Akaidi'l-Nesefiyye, Süleymaniye Ktp., Hac1 Mahmud Efendi Kol., nr. 1303, vr. 58; Mustafa b. Karabaş Ali, Cevâhiru'l-Akâid, Süleymaniye Ktp., Hacı Mahmud Efendi Kol., nr. 1393, vr. 58; Mustafa Ma'nevî Üsküdârî, Cevâhiru'l-Akâid, Konya Bölge Yazma Eser Ktp., Burdur İl Halk Kütüphanesi Kol., nr. 826/2, vr. 42b-88a. Bu tercümeler dışında mütercimini tespit edemediğimiz bir tercüme daha bulunmaktadır. Bkz. Karabaş Velî Alî b. Muhammed Kastamonulu, Şerhü Akâidin-Nesefìye, Ankara Milli Ktp., Ankara Adnan Ötüken İl Halk Kütüphanesi Kol., Nr. 1408, vr. 76.

${ }_{15}$ Örnek olarak bkz. Alaeddin Atvel b. Mehmed Karabaş Velî, Şerhu akâidi'n-Nesefiye bi-lisân et-tahkîk, İstanbul Büyükşehir Belediyesi, Osman Ergin Kitaplığı, OE_Yz_0476, vr. 25; Alaeddin Atvel b. Mehmed Karabaş Velî, Şerhu akâidi'n-Nesefiye bi-lisân et-tahkîk, İstanbul Büyükşehir Belediyesi, Osman Ergin Kitaplığı, OE_Yz_1189, vr. 35; Alaeddin Atvel b. Mehmed Karabaş Velî, Şerhu akâidi'n-Nesefiye bi-lisân et-tahkîk, İstanbul Büyükşehir Belediyesi, Osman Ergin Kitaplığı, OE_Yz_1531, vr. 21. Karabaş'ın şerini ve oğlu Mustafa Ma'nevî tarafından yapılan bu şerhin Osmanlıca tercümesini, Hitit Üniversitesi Temel İslam Bilimleri'nde bulunan Araştırma Görevlileri Osman AYDIN, Abdullah Sıtkı İLHAN ve Hafzullah GENÇ arkadaşlarımızla yayına hazırlamaktayız.

${ }^{16}$ Alaeddin Atvel b. Mehmed Karabaş Velî, Kitâbu Şerh'i Fusûsi'l-Hikem, Süleymaniye Ktp., Hacı Mahmut Efendi Bölümü, nr. 2225, vr. 1b-213a.

${ }^{17}$ Alaeddin Atvel b. Mehmed Karabaş Velî, Câmi'u'l-esrâri'l-fusûs, İstanbul Büyükşehir Belediyesi, Osman Ergin Kitaplığı, OE_Yz_0397, vr. 80; OE_Yz_0572/01, vr. 1-72.

${ }^{18}$ Alaeddin Atvel b. Mehmed Karabaş Velî, Mi'yâru't-Tarika, İstanbul Büyükşehir Belediyesi, Osman Ergin Kitaplığı, OE_Yz_0614/19, vr. 108a-115a.

19 Alaeddin Atvel b. Mehmed Karabaş Velî, Risâletü'd-Deverân, Süleymaniye Ktp., Hacı Mahmut Efendi Bölümü, nr. 2337, vr. 36-88. Risale hakkında yapılan müstakil bir çalışma için bkz. Fatih Keskin "Ali el-Atvel Karabaş Velî ve Rislâletü'd-Deverân'1", Selçuk Üniversitesi Sosyal Bilimler Enstitüsü, (Yayınlanmamış Yüksek Lisans Tezi), Konya 2004.

${ }^{20}$ Alaeddin Atvel b. Mehmed Karabaş Velî, Tarikatname, İstanbul Büyükşehir Belediyesi, Osman Ergin Kitaplı̆̆ı, OE_Yz_0382, vr. 37.

${ }^{21}$ Alaeddin Atvel b. Mehmed Karabaş Velî, Risale-i Esâsi'd-dîn, İstanbul Büyükşehir Belediyesi, Osman Ergin Kitaplığı, OE_Yz_0614/13, vr. 80b-82a.

${ }^{22}$ Alaeddin Atvel b. Mehmed Karabaş Velî, Risâle-i 'usûl-i erba'a, İstanbul Büyükşehir Belediyesi, Osman Ergin Kitaplığı, OE_Yz_0291/7, vr. 42a - 43; OE_Yz_0738/07, vr. 56b-58b. 
Şerhu Kaside-i Aşkiyye, ${ }^{23}$ Ta'birnâme, ${ }^{24}$ Risâle fi't-tasavouf,25 Beyanu Şerâit'i maa Usûl'i Aşere, ${ }^{26}$ Şerhu Hadîs, ${ }^{27}$ Tefsiru Sûre-i Tâhâa ${ }^{28}$ adında eserleri olduğu bilinmektedir. ${ }^{29}$

\section{Şerh'in te'lif sebebi:}

Karabaş'ın mukaddimede dile getirdiği hususlar, şerhin telif amacına ve metoduna dair önemli açıklamalar içermektedir. Nesefî̀nin metninde yer alan bazı ibareler, sûfî itikadına işaret ve remz kabul edilmiştir. Bu işaret ve remzler arasında mümkün olanların sözle, sözle belirtilmesi mümkün olmayanların ise izhar edilmek suretiyle şerh edildiği belirtilmiştir. Mukaddimedeki ifadeler, Karabaş'ın şerh metodu hakkında ipuçları verdiği gibi tasavvuf epistemolojisini de yansıtır mahiyettedir. Bu ifadeler dışında, şerhin yazım sebebi de mukaddimede kendini göstermektedir. Buna göre Karabaş, Kadızadeliler ve Sivasiler çekişmesinde dönemin sosyo-politik gerçekliğini yansıtırcasına sûfîlerin Ehl-i Sünnet olmadıkları “'zam-1

${ }^{23}$ Alaeddin Atvel b. Mehmed Karabaş Velî, Şerhu Kaside-i Aşkiyye, İstanbul Büyükşehir Belediyesi, Osman Ergin Kitaplığı, OE_Yz_0917/02, vr. 7b-11.

${ }^{24}$ Alaeddin Atvel b. Mehmed Karabaş Velî, Tabirname, İstanbul Büyükşehir Belediyesi, Osman Ergin Kitaplığı, OE_Yz_0614/08, vr. 42b-44b.

${ }^{25}$ Alaeddin Atvel b. Mehmed Karabaş Velî, Risâle fi't-Tasavvuf, Süleymaniye Ktp., Tırnovalı Bölümü, nr. 356, vr. 29b-30a.

${ }^{26}$ Alaeddin Atvel b. Mehmed Karabaş Velî, Şeraîtü'l-İslâm maa usuli aşere, İstanbul Büyükşehir Belediyesi, Osman Ergin Kitaplı̆̆ı, OE_Yz_0697/08, vr. 119a$122 b$.

${ }^{27}$ Alaeddin Atvel b. Mehmed Karabaş Velî, Şerhu hadîs-i Hubbibe ileyye min dünyaküm, Süleymaniye Ktp., Reşid Efendi Bölümü, nr. 409/02, vr. 111a-112b; Kerim Kara İBB Osman Ergin Yazmaları, 1063/2'de Mi'yâru't-Tarîka şeklinde kayıtlı olsa da, ilgili kayıttaki risalenin mezkur hadisin şerhi olduğu tespitine yer vermektedir. Krş. Kerim Kara, “Karabaş Velî Hayatı - Eserleri ve Fikirleri, s. 104.

${ }^{28}$ Alaeddin Atvel b. Mehmed Karabaş Velî, Tefsir-i Sûre-i Tâhâ, İstanbul Büyükşehir Belediyesi, Osman Ergin Kitaplığı, OE_Yz_0614/01, vr. 1b-4a.

${ }^{29}$ Karabaş'ın eserleri ülkemizde kütüphanelerde oldukça fazladır. Biz burada örnek olması için bir tanesini zikretmekle yetindik. Eserlerinin bulunduğu kütüphaneler hakkında ve bazı risalelerinin içerikleri hakkında detaylı bilgi için bkz. Bursalı Mehmed Tahir Efendi, Osmanlı Müellifleri, Haz: A. Fikri Yavuz-İsmail Özen, Meral Yay., İstanbul, c. I, s. 138; Kerim Kara, "Karabaş Velî Hayatı - Eserleri ve Fikirleri"., ss. 82-105; Kerim Kara, "Karabaş Veli", DIAA, y1l: 2001, c. XXIV, ss. 370; Fatih Keskin "Ali el-Atvel Karabaş Velî ve Rislâletü'd-Deverân'1", ss. 2332. 
fâsit ve zann-ı bâtılına" karşın Nesefi'nin akâidi'ni şerh ettiğine hususen değinir. ${ }^{30}$

Şerhin sûfîlerin de Ehl-i Sünnet olduklarını ortaya koymayı amaçladığ 1 dikkate alındığında, Nesefî̀n nin akâid metninin tercih sebebi de daha da anlaşılır olmaktadır. Bu, aynı zamanda Osmanlı toplumunda hakim Sünni paradigma ${ }^{31}$ hakkında da bazı önemli işaretleri barındırmaktadır. Toplumun birçok kesimine yayılan sûfîfakîh mücadelesi içerisinde Sünni kimliğin beyanı için sûfînin, Nesefî́y yi tercih etmesi, çekişmenin tarafları açısından Nesefî akâidi'nin Osmanlı'da hakim Sünni paradigmayı temsil eden bir eser niteliğine sahip olduğunu ortaya koymaktadır. Bununla birlikte böyle bir şerh faaliyetinin taraflardan Karabaş'a ait olması, mevcut durumun sûfîler açısından daha zor şartları barındırdığı yorumunu yapmamıza olanak tanımaktadır. Karabaş'ın Ehl-i Sünnet olduğunu açıklama ihtiyacı hissetmesi ve bunu medresenin temel metinlerinden olan Nesefî akâid'i üzerinden gerçekleştirmesi, hakim kelâm geleneğine dayanmanın amaçlandığını ve kelâm ilminin temel metinlerinin her iki taraf açısından belirleyici ve saygın ortak bir otorite kabul edildiğini göstermektedir.

\section{Varlık ve Bilgi Hakkındaki Değerlendirmeler}

Nesefî̀nin ulemanın genel kanaati olarak eşyanın ontik anlamda gerçekliğini ortaya koymak için "eşyanın hakikatleri sabittir" ifadesi ve bu görüşü dayandırdığı "ehl-i hak", Karabaş tarafından sûfî epistemoloji ve ontoloji içerisinde değerlendirilmiştir. Buna göre "ehl-i hak", veli manasına hamledilmiş ve zâhir ulemasının aksine "keşf ve şühûd" a salahiyetleri dolayısıyla hatadan uzak değerlendirilen ehl-i keşf ve'ş-şühûd ile özdeşleştirilmiştir. ${ }^{32} \mathrm{Bu}$ surette de

\footnotetext{
${ }^{30}$ Ali Alaeddin Atvel b. Mehmed Karabaş Veli, Şerhu akâidi'n-Nesefi bi lisâni'ttahkîk, İstanbul Büyükşehir Belediyesi Osman Ergin Yazmaları, OE_Yz_0476, vr. 1b-2a; OE_Yz_1189, vr. 1b-2a; OE_Yz_1531, vr. 1b; a.g. m., Şerhu Akâidi'n-Nesefî, Bursa İnebey Yazma Eser Ktp., Orhan Camii Bölümü, nr. 16 Or 613/2, vr. 100b.

${ }^{31}$ Nesefî'nin akâid metnini, Osmanlı'nın toplumsal hayatını yansıtan sembollerden biri olarak değerlendirdiğimizi belirtmek isteriz. Paradigmanın toplumsal hayatta çeşitli şekillerde üretilen semboller olarak değerlendirildiği bir yorum için bkz. Mehmet Evkuran, Sünni Paradigmayı Anlamak - Bir Ekolün Politik ve Teolojik Yapılanması, Ankara Okulu Yay., Ankara 2016, s. 28.

32 Karabaş Veli, Şerhu akâidi'n-Nesefi bi lisâni't-tahkîk, İstanbul Büyükşehir Belediyesi Osman Ergin Yazmalar1, OE_Yz_0476, vr. 2/a-2/b; OE_Yz_1189, vr. 2/b;
} 
ehl-i hak kullanımının veli yani ehl-i marifet için daha uygun olacağı yorumu öne çıkarılmıştır. Açıkça anlaşıldığı üzere şârih metnin ilk ifadelerini tasavvuf felsefesine uygun yorumlamaya çalışmış ve bir anlamda metnin ne söylediğinden öte sûfî gelenek açısından şerhin devamlılığını sağlayabilecek epistemolojik ve etimolojik meşruiyet zeminini oluşturmuştur. Bu kavramsal dönüşümü takip eden husus ise "eşyanın hakikatlerinin sâbitliği/gerçekliği" yorumunda karşımıza çıkmaktadır.

Bir kelam metninde eşyanın harici gerçekliğini ve bu gerçekliğin bilinirliğini dile getirmek için kullanılan ifade, ${ }^{33}$ Karabaş tarafından İbn Arabî etkisini de gösterir mahiyette ayân-1 sâbite ${ }^{34}$ olarak açıklanmıştır. Mütekellimler açısından sıfatlar ve eşyanın Allah'ın ezeli ilmindeki bulunmasıyla ilişkilendirilmeyen bu ibare, Karabaş tarafından esmâ-i husnâ ile kâim şeklinde değerlendirilerek Nesefî'nin umûr-i küllî yani ayân-ı sabiteye işaret ettiği varsayılmıştır. ${ }^{35}$ Eşyânın esmâ-i husnâ ile kâim kendi zatlarında ise ma'dûm olduğunu söyleyen şârih, bu yorumunun dayandığı varlık anlayışını daha sonra zikreder ve "vücûdu/varlığı" mutlak, ma'kûl ve aynî olarak tasnif eder. Varlığı üç kategoride ele alan Karabaş, mutlak varlık ile Mutlak zât, ma'kûl varlık ile hakâik yani umûr-i küllî, aynî varlık ile de duyuya konu olan eşyanın gerçekliğini kastetmiş-

OE_Yz_1531,vr. 2/b. Ayrıca sûfî ontolojiye dair bir değerlendirme için bkz. Mehmet Evkuran, Ahlak Hakikat ve Kimlik-İslam Kelamında Ahlak Problemi-, Araştırma Yay., I. Bsk., Ankara 2013, ss. 97-104.

33 Ömer Nasuhi Bilmen, Muvazzah İlmi Kelam, Bilmen Yayınevi, İstanbul 1972, s. 12.

${ }^{34}$ A'yân-1 sâbite hakkında detaylı bilgi için bkz. Mahmut Erol Kılıç, “Muhyiddin İbnu'l-Arabi'de Varlık ve Mertebeleri: Vücud ve Meratibu'l-vücud", Marmara Üniversitesi Sosyal Bilimler Enstitüsü, Doktora Tezi, İstanbul 1995, ss. 243-245; Mahmud Erol Kılıç, İbnü'l-Arabî, İSAM Yay., 1. Bsk, İstanbul 2015, ss. 110-113; Muhyiddin İbnu'l-Arabî, Fusûsu'l-Hikem (Tercüme ve Şerhi), trc.-şrh: Ahmed Avni Konuk, haz: Mustafa Tahranlı - Selçuk Eraydın, Marmara Üniversitesi İlahiyat Fakültesi Yay., 6.Bsk., İstanbul 2014, c. I, s. 143, 154, 258, vd.; Süleyman Uludă̆, "A'yân-1 Sâbite", DİA, İstanbul, Yıl: 1991, c. IV, ss. 198-199; Safvet Kemalüddin Yetkin, "Kelamdan Tasavvufa", Ankara Üniversitesi IIlahiyat Fakültesi Dergisi, y1l: 1953, c. II, sy: 4, ss. 14-16.

${ }^{35}$ Karabaş'ın şerhindeki bu hususa uzun yıllar önce dikkat çeken bir çalışma için bkz. Safvet Kemalüddin Yetkin, "Kelamdan Tasavvufa", Ankara Üniversitesi İlahiyat Fakültesi Dergisi, yıl: 1953, c. II, sy: 4, ss. 14-15. 
tir. Merâtib-i vücûdu hazerât-1 selâse ile değerlendiren şârih, Nesefî̀nin "hakâik" kavramını, kendi ontolojisinde ikinci kısma yani eşyanın dış gerçekliğinin/aynî varlığının bulunmayıp hepsinin ilmi ezelî̀'de bulunuşuna, esmâ ile kâim olup aslında ma'dûm oluşuna işaret saymıştır. ${ }^{36}$

Tasavvuf felsefesinin merâtib-i vücûd yaklaşımını oldukça açık bir anlatımla ortaya koyan bu ifadeler arasında eşya hakkında aynî varlık, hakâik hakkında da ma'kûl varlık kavramsallaştırması, şârihin ilgili yorum ve değerlendirmelerinin temelinde yatan etimolojik ve epistemolojik dayanağı göstermektedir. Buna göre "hakâik" kavramının kendi sisteminde taşıdığı anlamın, Nesefî tarafından da göz önünde alınarak kaleme alındığı Karabaş açısından müsellem bir husustur. Bu surette de müellifin kullandığı bir kavram, şarih tarafından kendi anlam küresi içerisinde değerlendirilmiş ve şerh türü telifler açısında oldukça özgün bir yaklaşım ortaya koyulmuştur. Özgün ve özlü bir akâid metni, tam anlamılla tasavvuf felsefesinin varlık anlayışını yansıtan bir veçheye büründürülmüştür. Oysa bu ibarenin eşyanın dış gerçekliğini ortaya koyduğu Nesefî açısından müsellem olmakla birlikte metnin akışı açısından da bir zorunluluktur.

"Eşyanın doğasını reddetme" metafizik, "eşyanın bilgisini mümkün görmeme" de epistemolojik bir tez olarak ortaya çıktığından, ${ }^{37}$ buna karşı olarak kelamcıların eşyanın doğasının bulunduğunu ve bilindiğini ifade etmeleri de metafizik ve epistemolojik birer tez şeklinde kendisini sunmaktadır. Bu sebeple Nesefî'nin metnin devamında "sûfistâiyyenin hilafına" açıklaması eşyanın dış gerçekliğinin bilinirliğini ve duyuların duyulurlara dair verdiği bilginin imkanını ortaya koymaya yöneliktir. Çünkü sofistlerin “bir şey yoktur, olsaydı da bilinemezdi ve bilinseydi de başkalarına bildirilemezdi" şeklinde formüle edilen ve diğer temel savları dikkate alındığında, insanı hakikatin ölçüsü kılan anlayışlarıyla varlığın

\footnotetext{
${ }^{36}$ Karabaş Veli, Şerhu akâidi'n-Nesefi bi lisâni't-tahkîk, İstanbul Büyükşehir Belediyesi Osman Ergin Yazmaları, OE_Yz_0476, vr. 2/a-3/b; OE_Yz_1189, vr. 2/b-4/a; OE_Yz_1531, vr. 2/a-3/b.

${ }^{37}$ Ahmet Arslan, İlkçă̆ Felsefe Tarihi 4 : Helenistik Dönem Felsefesi: Epikurosçular Stoacılar Septikler, İstanbul Bilgi Üniversitesi Yay., 2. Bsk., İstanbul 2010, ss. 440443.
} 
gerçekliğinde izafiliği öne çıardıkları görülür. ${ }^{38} \mathrm{Bu}$ surette de varolanın, kelami epistemolojide söylemek gerekirse şeyin hakikatinin yani doğada bulunduğu haliyle şeyin bilinirliğinde izafiyet iddiasında olanlardır. Bu izafiyet yaklaşımı şeyin hakikatinin olmadığı ve bilinemeyeceği iddiasını ortaya çıkarmaktadır. Bu surette Nesefî'nin eşyanın gerçekliği, bilinir oluşu ve sûfistâiyyenin hilafına şeklinde bir bütünlük arz eden açıklamaları, Karabaş'ın yorumu ile birlikte farklı bir alana yönelmiştir. Bu yönelişin doğurduğu sonuçlardan biri, sûfistâiyyenin eşyanın hakikatlerini reddetmesiyle kastedilenin, umûr-i küllî yani esmâ-i hüsnâ'yı reddetmeleri olmak durumdadır. Oysa sûfistâiyyenin iddiaları, kelamcıların uzun süredir mücadele ettiği ve "eşyanın hakikatlerinin sabit olduğunu" çeşitli şekillerde ortaya koymaya çalıştıkları bilinen bir husustur. ${ }^{39}$ Ayrıca mütekellimlerin duyuların gerçekliğini reddeden sofistlere yönelik duyusal anlamda bir eziyeti salık vermeleri de bu hususu desteklemektedir. ${ }^{40}$ Bunun dişında a'yân-1 sâbite'nin vücûdî değil de, ademî olduğ ${ }^{41}$ dikkate alındığında, Karabaş'in bu yorumunun,

38 Sofistler hakkında detaylı bilgi için bkz. Macit Gökberk, Felsefe Tarihi, Remzi Kitabevi, 5. Bsk., İstanbul 1985, ss. 42-46; Cavit Sunar, Varlık Hakkında Ana Düşünceler, Ankara Üniversitesi İlahiyat Fakültesi Yay., Ankara 1977, ss. 53-61; Ebû İshâk İbrahim b. İsmâîl b. Ahmed b. İshâk es-Saffâr el-Buhârî, Telhîsu'l-edille li kavâidi't-tevhid, thk: Hişam İbrahim Mahmud, Dâru's-Selâm, 1. Bsk., Kâhire 2010/1431, ss. 157-162. Sufistâiyye kavramının Yunan kaynaklı Skepticism ve Sofism kavramlarından hangisini karşıladığı hususunda bulunan muğlaklık hakkında bkz. Şaban Ali Düzgün, Nesefi ve İslam Filozoflarına Göre Allah Alem İlişkisi, Akçağ Yay., 1. Bsk., Ankara 1998, s. 21.

${ }^{39}$ Kelamcıların duyusal bilginin gerçekliği yansıtmadığını iddia eden sufistaiyyeye karşı mücadelesi kelamın ilk dönemlerine kadar uzanan bir olgudur. Mu'tezile bilginlerinin de bu hususta oldukça mücadele ettikleri ve duyuların sağladığı bilginin gerçekliğini ortaya koymak için tartışmalara girdikleri bilinmektedir. İbn Abdürrabih, İkdü'l-ferîd, nşr: Ahmed Emin vd., Lecnetü't-Te'lif ve't-Terceme, Kahire 1389/1969, c. II, ss. 407-408; Bkz. İlhan Kutluer, "Lâedriyye", DİA, c. XXVII, ss. 41-42; İbrahim Emiroğlu, "Sûfestâiyye", DİA, c. XXXVII, ss. 468-46; Düzgün, Nesefí, ss. 21-22.

${ }^{40}$ Hilmi Demir, Delil ve İstidlâlin Mantık̂̀ Yapısı - İlk Dönem Sünni Kelam Örneği, Türkiye Diyanet Vakfı İslâm Araştırmaları Merkezi (ISAM) Yay., İstanbul 2012, ss. 25-30.

${ }^{41}$ Halil İbrahim Şimşek “İsmail Fenni Ertuğrul'un İbnü'l-Arabî ve Vahdet-i Vücud Savunması", Tasavvuf: İlmi ve Akademik Araştırmalar Dergisi (ínnü'l-Arabî Özel Sayısl), yıl: 9 (2008), sayı: 21, s. 206-207; Süleyman Uludağ, "A'yân-1 Sâbite", DİA, İstanbul, Yıl: 1991, c. IV, ss. 199. Ayan-1 sâbite ve Mu'tezile'nin ma'dûm yaklaş1mın mukayese edildiği ve ayrıca Kelamcıların vahdet-i vücud üzerindeki etkileri 
"ma' dûmun şey" olmadığını açıkça zikreden Nesefî' nin ve bağlı bulunduğu kelâmî geleneğin genel kanaatinin hilafına olduğu rahatlıkla söylenebilir. ${ }^{42}$

Varlığı Mutlak, ma'kûl ve aynî şekilde tasnif eden Karabaş, Ehl-i Sünnet' in kelam geleneğinin zât-sıfat ilişkisi hakkındaki “zatının ne aynı ne de gayrıdır" kavramsallaştırmasını, oldukça mahir bir şekilde merâtib-i vücûd'a uygulamış ve vahdet-i vücûdu Sünni kelam disiplininin kavram dünyası ile mezcetmiştir. Buna göre öncelikle eşyanın varlığının/aynî varlığın ma'kûl varlıktan başka; ma'kûl varlığın da Mutlak Varlık dışında varlığının/vücudunun olmadığını belirterek varlığın birliği anlayışını ortaya koymuştur. Bunun akabinde "و لا عينه ولا غيره" diyerek ma'kûl varlığın Mutlak Varlık'ın ne aynı/kendisi ne de gayrı; aynî varlığın da ma'kûl varlığın ne aynı/kendisi ne de gayrı olduğu yorumunda bulunmuştur. Daha sonra ise varlığın ayniyetinin hüküm itibariyle, gayriyetinin de zât itibariyle olmadığını söyleyerek "ne aynı ne de gayrıdır" ifadesini açıklamaktadır. Allah'ın zâtı hariç her şeyin yok olacağını belirten ayeti ${ }^{43}$ de bu açıklamaları için son bir dayanak kılmış ve bu şekilde de Mutlak Varlık'tan başka varlığın hakiki anlamda var olmadığını, diğer varlıkların (ma'kûl ve aynî varlıkların) Allah'ta fenâ bulacaklarına işaret etmiştir. ${ }^{44}$ "Hakâik" kavramının sûfi lite-

hakkında bkz. Ebu'l-Alâ el-Afîfî, "Mu'tezile'nin Ma'dum Nazariyesi ile İbn Arabî'nin A'yân-1 Sabite Nazariyesinin Karşılaştırılması", çev. Cağfer Karadaş, Uludağ Üniversitesi Illahiyat Fakültesi Dergisi, y1l: 1997, c. 6, sayı: 6, ss. 267-276; Cağfer Karadaş, "Kelamcıların İbn Arabî Düşüncesine Etkisi”, Uludağ Üniversitesi İlahiyat Fakültesi Dergisi, yıl: 2002, say1: 2, c. 12, ss. 87-96.

${ }^{42}$ Eşyanın hakikatleri, bunların bilinebilirliği hakkındaki yorumlarımızın dayandığı kaynaklar olarak bkz. Ebû Mansûr Muhammed b. Muhammed el-Mâtürîdî es-Semerkandî, Kitâbu't-Tevhîd, thk: Bekir Topaloğlu-Muhammed Aruçi, Dâr-u Sâdr-Mektebetü'1-İrşâd, 2. Bsk., Beyrut 2010, ss. 69-70; Pezdevî, Usûli'd-Dîn (Ehli Sünnet Akâidi), çev: Şerafeddin Gölcük, Kayıhan Yay., İstanbul 2015, ss. 26-27.; Ebu'l-Muîn Meymûn b. Muhammed en-Nesefî, Tabsiratü'l-edille fì usûli'd-dîn, thk: Hüseyin Atay, Diyanet İşleri Başkanlığı Yay., Ankara 1993, c. I, ss. 20-21; Taftazânî, Kelam İlmi, ss. 85-86; Nûreddîn es-Sâbûnî, el-Bidâye fì usûli'd-dîn (Mâtürîdiyye Akâidi), Çev: Bekir Topaloğlu, Diyanet İşleri Başkanlığı Yay., 8. Bask1, Ankara 2005, ss. 16-17 (tercüme ss. 55-57)

${ }^{43}$ El-Kasas, 28/88.

${ }^{44}$ Burada özet olarak verdiğimiz ne aynıdır yani kendisidir ne gayrıdır hususunu, Karabaş şerhinde uzunca açıklamaya çalışmaktadır. Bunun için taş, taşın 
ratürdeki anlamı, Karabaş için remz ve işaret anlamı taşısa da, şârihin değerlendirmelerinin, müellifin ibareleri ve düşüncelerinin bütünlüğü dikkate alındığında, tutarlı olduğunu söylemek güç görünmektedir.

Şârih, "ehl-i hak" kavramıyla ilgili açıklamalarına devam ederken oldukça sistematik bir şekilde hareket etmektedir. Buna göre Nesefî’nin "ehl-i hak" ile insanların kısım kısım olduklarına işaret ettiğini söyledikten sonra, bunların da kâfir, mü'min; mü'minin âlim ve âlim olmayan; âlim olmayanın filozoflar gibi nazar-ı fikrî ve delil-i aklî, âlim olanın ise keşf-i ma'nevî ve şühûd-u hakîki'yi tarik kabul edenler olduğunu zikreder. Karabaşın bu ifadelerinde belirleyici olanın, âlimi, âlim kılacak nitelik olan ilmin hakikate dair olmasından öte, ilme sahip olma yöntemi olduğu görülür. Buradan anlaşıldığı üzere aklî ve nazarî ilim, sahibini âlim kılmamakta; ma'nevî bir keşf ile elde edilen ilim kişiye âlimlik vasfını kazandırmaktadır. Bununla birlikte Karabaş'a göre, nazar ve akli delil ile hareket eden hatadan uzak kalamazken, keşf ve şühûdda hata söz konusu değildir. Bu ifadelerin hakikatin tekelleştirilmesi şeklinde yorumlanabileceği gibi bizce dönemin sosyo-politik olaylarının şârihin şerhte böylesine sert bir üslup benimsemesine neden olduğunun söylenmesi daha uygun görünmektedir. Aksi takdirde keşf sahibinin tam anlamıyla hatadan uzak kabul edilmesi, belli kişilere (keşf sahibi gerçek ehl-i hak olanlara) ismet sıfatı nispet etme anlamına gelebileceğinden, temel İslâmî prensiplerle çelişecektir. Bununla birlikte bilgi, tek yönteme irca edilmiş olacaktır ki Nesefî́n nin metni açısından bu yorumun "vakıaya mutabık olmadığı" izahtan varestedir. Zira esbâbü'l-'ilm için zikrettiği havass-1 selime, haber-i sadık ve akıl, vakıaya mutabık bir bilgiyi ve bu bilginin elde ediliş tarzlarını ifade etmektedir. ${ }^{45}$

İlmin keşf ve şühûd ile, alim olmanın da keşf sahibi olmakla birlikte değerlendirildiği ve aklî-nazarî yöntemin dişlandığı yorumlar, daha önce eşyanın gerçekliği hakkında belirttiğimiz gibi, metnin

yanması, taşın ışı̆̆ı, ayna, aynaya bakan, aynada görünen vb. misallerden yararlanmaktadır. Karabaş Veli, Şerhu akâidi'n-Nesefi bi lisâni't-tahkîk, İstanbul Büyükşehir Belediyesi, OE_Yz_0476, vr. 2/b-9/a; OE_Yz_1189, vr. 2/b/a-4/a; OE_Yz_1531, vr. 2/a-9/a.

${ }^{45}$ Karabaş Veli, Şerhu akâidi'n-Nesefi bi lisâni't-tahkîk, İstanbul Büyükşehir Belediyesi, OE_Yz_0476, vr.3/b-8/a; OE_Yz_1189, vr. 4/a-11/a; OE_Yz_1531, vr.3/a-7/a. 
bütünlüğü dikkate alındığında kabul edilebilir görünmemektedir. Zira Nesefî'nin esbâbü'l-'ilm içinde zikrettiği unsurların, kelâmî epistemolojiyi yansıttığı görülmektedir. Şârihin, esbâbü'l-'ilm üzerinde yaptığı şerh oldukça dikkat çekici olmasına rağmen, Nesefî'nin akıl, havâss-1 selîme ve haber-i sâdık şeklinde belirttiği bilgi edinmenin yolları içerisinde keşf ve şühûda değinmemesi ve aklın bir bilgi kaynağı olduğunu söylemesi, şârihin alim olmama üzerinde yaptığı şerhiyle çeliştiğinin farkında olmaması ya da buna hiç değinmemesi daha da dikkat çekici görünmektedir. Bundan daha da öte "aklı, bilgi kaynaklarının başı/reisi" olarak şerh etmesine rağmen, "aklî delil sahibinin alim olmaması" şeklindeki açıklaması, şârihin esbâbü'l'-'ilm konusunda kendi içinde çeliştiğini ve farklılaştığını göstermektedir. ${ }^{46}$

Şârih, kelâmî geleneğin genel kanaatinin korunduğu esbâbü'l'ilm bahsinde metnin taşıdığı anlamla uyumlu bir şerh yaparken; keşfin hakiki bilgi kaynağı (hatadan uzak bir bilgi kaynağı) olduğu şeklindeki sûfî kanaati de daha önce metin içerisinde öne çıkarmıştır. Nesefî'nin havass-1 selimeyi diğerlerine öncelemesinin metodolojik bir içeriğe sahip olduğunu belirtmekte; akıl ve haberin hükümlerini icra etmek için sağlam duyu organları ile elde edilmiş bilgiye muhtaç olduğunu söylemektedir. Bu bölümde aklı ele alırken akıl, kalp, nefs ve ruh kavramlarının ehl-i hak nazarında aslında bir ve aynı şey olduklarını ancak itibarları noktasında farklılığın olduğunu belirtmektedir. ${ }^{47}$

Esbâbü'l-'ilm hakkındaki açıklamaları şerhte önemli bir yer teşkil etmektedir. Nesefî̀nin ilgili açıklamalarının dışındaki yerlerde de Karabaş, tasavvuf felsefesinin bilgi teorisini yansıtan açılamalar vermekten geri durmamıştır. Duyu organları, haber ve akıl arasındaki ilişkiye hususen değinen şârih, istidlâl ve nazar ehline göre ilmin asıl kaynağının akılla birlikte duyulardan elde edilen bilgi şeklinde ele alındığını zikreder. Sûfîlerin de ilmin sebeplerini üç kabul ettiklerini ancak bu sebeplerin aynı olmadığına dikkat çe-

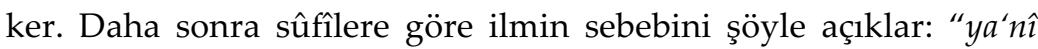

\footnotetext{
${ }^{46}$ Karabaş Veli, Şerhu akâidi'n-Nesefi bi lisâni't-tahkîk, İstanbul Büyükşehir Belediyesi, OE_Yz_0476, vr. 5/a-8/b; OE_Yz_1189, vr. 7/b-11/a;OE_Yz_1531, vr. 4/b-7/a. ${ }^{47}$ Karabaş Veli, Şerhu akâidi'n-Nesefi bi lisâni't-tahkîk, İstanbul Büyükşehir Belediyesi, OE_Yz_0476, vr. 5/a-; OE_Yz_1189, vr. 6/b-7/a; OE_Yz_1531, vr. 4/b-5/a.
} 
sûfiler katında olan vücudun biri ma'l̂ิmun vücududur isterse zihnî olsun isterse aynî olsun. Ve biri dahî tâlibden olan vücûddur. Ve biri dahî ilm-i hakikatten olan i'ta' (اعطاء) demek olur. ${ }^{48}$ Bunlar doğrudan ilmin sebebi olmaktan öte bilinenlerin taksimini ifade etmektedir. Zira daha sonraki açıklamaları da zuhur sebepleri üzerinde durmakta ve yukarıdaki açiklamalarına uygun olarak üç aşamadan bahsetmektedir. Bunlar zâtın kendisi, irâdesi ve "kün" emridir. Bu şekilde varlığın zât, irade ve küm emriyle ortaya çıkışını anlatan Karabaş, zuhur teorisini ve mertebesini de ortaya koymaktadır. ${ }^{49}$

Bilgi kaynakları konusunda karşımıza çıkan önemli bir yorum da, Karabaş'ın aklı batınî bir his kabul etmesidir. Karabaşa havass-1 bâtınî yorumunu yaptıran husus, Nesefî'nin havass-ı selîme açılamasıdır. Bu açıklama Karabaş tarafından bâtınî anlamda da bazı duyuların olması gerektiği, bunun da beş olmasının kaçınılmaz olduğunu şeklinde anlaşılmıştır. Aklı batınî bir duyu melekesi kabul ettikten sonra, aklı başka bir yerde idrak gücü şeklinde ele almaktadır, Nesefí'nin akıl ile diğer bâtınî melekleri kastettiği ve aklı zikretmekle yetindiği belirtilmiştir. Aklı zikretmekle yetinilmesi, Karabaş tarafından aklın "bâtınî hislerin reisi olup diğerlerinin ona tabi olduğu" $u^{\prime 0}$ yani en önemli olan unsurun belirtilip kendisine bağlı olanların da onun zikredilmesiyle hatıra geleceği ile gerekçelendirilmiştir. Buna rağmen Karabaş'ın beş adet olduğunu söylediği havass-ı bâtına hakkında akıl dışında bir melekeyi zikrettiği de dikkat çekmemektedir. Karabaş'ın ilim anlayışını yansıtan en önemli ifadeler de burada kendine yer bulmaktadır. Karabaş'a göre ilim,

\footnotetext{
${ }^{48}$ Karabaş Veli, Şerhu akâidi'n-Nesefi bi lisâni't-tahkîk, İstanbul Büyükşehir Belediyesi, OE_Yz_0476, vr. 5/b-6/a; OE_Yz_1189, vr. 7/b; OE_Yz_1531, vr. 5/a. Tercümeyi oğlu Mustafa el- Ma'nevî'nin tercümesinden iktibas ettik. Ayrıca Mustafa Ma'nevî tercümesinde "ehline ma'lumdur" şeklinde bir katkı ve müdahalede bulunmaktadır. Bu açıklama, metnin anlamının aslında kapalı olduğuna; ancak bu ilimle ilgilenen kişiler için anlaşılmaz olmaktan öte bilinen bir husus olduğuna işaret anlamı taşımaktadır. Mustafa el-Ma'nevî, Terceme-i Şerhi'l-Akaidi'l-Nesefiyye, Süleymaniye Ktp., Hacı Mahmud Efendi Kol., nr. 1303, vr. 16/b; Mustafa b. Karabaş Ali, Cevâhiru'l-Akâid, Süleymaniye Ktp., Hacı Mahmud Efendi Kol., nr. 1393, vr. 14/a-14/b.

${ }^{49}$ Karabaş Veli, Şerhu akâidi'n-Nesefi bi lisâni't-tahkîk, İstanbul Büyükşehir Belediyesi, OE_Yz_0476, vr. 5/a-5/b; OE_Yz_1189, vr. 4/a-6/b; OE_Yz_1531, vr. 3/a-5/a. ${ }^{50}$ Karabaş Veli, Şerhu akâidi'n-Nesefi bi lisâni't-tahkîk, İstanbul Büyükşehir Belediyesi, OE_Yz_0476, vr. 5/a-5/b; OE_Yz_1189, vr. 6/b; OE_Yz_1531, vr. 4/b.
} 
kişinin zâhir ve bâtın hislerinin sağlıklı ve selim olmasına bağlıdır. Böyle kişiler ilmin nuruna muttali' olabilirler. ${ }^{51}$

Dikkat çeken hususlardan biri de şudur: Nesefî insanlar için bilgi kaynağının üç olduğunu ve ilhamın bir bilgi kaynağı olmad1ğını söyleyip bunu yine ehl-i hak dediği bir zümreden nakletmektedir. Bu noktada Karabaş'ın ehl-i hak için yaptığı açıklamalar dikkate alındığında, ya da Nesefî́nin ehl-i hak ile Karabaş'ın şerhinin dayandığı remz ve işaretleri kastettiği varsayıldığında, esbâbü'l-'ilmin üç olduğunu ve ilhamın delil olamayacağını söyleyenler bizzat velîler, keşf-i ma'nevî sahipleri olacaktır. Bu ihtimal söz konusu değilse, zira Karabaş için bu anlam mümkün görünmemektedir, Nesefî́nin ehl-i hak kullanımı hakkında Karabaş'ın yaptığı şerh ve tahlilin, yukarıda bahsettiğimiz üzere, uygun olmadığı söylenebilir. Daha açık bir ifade ile şârihin ehl-i hak kavramını bir işaret ve remz kabul etmesinin güç olduğu anlaşılır.

Eşyanın hakikatlerini umûr-i küllî/esmâ-i husnâ, hatadan uzak ilmin de keşf ve şuhûd yöntemiyle elde edileceğini, âlimin de و العلم " keşf-i ma'nevî sahibi olduğunu belirttikten sonra Nesefî̀nin "بها متحقق ifadesini şerh ederken, hakâik olmasaydı eşyanın ortaya çıkmayacağı ifadelerine yer vermiştir. Karabaş daha sonra Nesefî́nin العلم ile keşf ve müşahade sahibine işaret ettiğini; "sofislerin aksine" şeklinde geçen ifadenin de bu yorumu desteklediğini düşünmektedir. ${ }^{52}$ Bu açıklama Karabaş'ın şerhinin kendi içinde bir bütünlüğ̈̈ barındırdığını göstermekle birlikte, eşyanın bilgisinin gerçek olduğuna değinen ve duyularla elde edilen bu bilgiden şüphe edenlere bir reddiye niteliği taşıyan metnin aslının da bir değişim ve dönüşümüdür. Bu husus, şerhin salt tekrar ve açıklama olmayıp asıl metnin değişim ve dönüşümünü de ifade eden yaklaşımları da ${ }^{53}$ destekler mahiyettedir. Karabaş' 1 n şerhini belirleyen anlayışın vahdet-i vücûd olduğu, "isimlerin tamamının nispetinin Tek Bir varlığa/Mutlak varlığa/Vâcibu'l-vücûda" dayandığını

\footnotetext{
${ }^{51}$ Karabaş Veli, Şerhu akâidi'n-Nesefi bi lisâni't-tahkîk, İstanbul Büyükşehir Belediyesi, OE_Yz_0476, vr. 5/a-5/b; OE_Yz_1189, vr. 6/b; OE_Yz_1531, vr. 4/b.

${ }^{52}$ Karabaş Veli, Şerhu akâidi'n-Nesefi bi lisâni't-tahkîk, İstanbul Büyükşehir Belediyesi, OE_Yz_0476, vr.3/b; OE_Yz_1189, vr. 4/a-4/b; OE_Yz_1531, vr. 3/a-3/b.

53 İsmail Kara, İlim Bilmez Tarih Hatırlamaz, ss. 27, 29, 109, vd.
} 
belirten ifadelerinde belirgin bir şekilde karşımıza çıkmaktadır. ${ }^{54}$ Hakâik Hakk'ın bir zâtî sıfatı, eşyâ da bu hakikatlerin birer gölgesi mesabesindedir.

Karabaş varlık ve varoluş hakkındaki açıklamalarını "Allah'ın ilm-i ezelîsinde bulunan şeylerin varlığa geldiğini; bu surette hiçbir şeyin yoktan var olmadığı" sözleriyle daha açık ve bütüncül bir şekilde ortaya koymaktadır. Bu itibarla mahlukların bilgisi, Allah'ın ilminde bulunmakta; Allah'ın ilminde olmayan şeylerin varlı̆g 1 mümkün olmamaktadır. Bu açıklamaları mahlukların Allah'ın ilmi ezelîde bulunuşunun kadim; zuhurlarının ise hâdis olduğu yorumu takip etmektedir. Bu hususla alakalı birçok ulemanın fikir ortaya attığını belirten Karabaş, kendisinin de paylaştığı bu yorumun, doğru haber veren Allah'tan geldiğini; keşf ve suhûd ile elde edildiğini belirterek ilgili yorumu Allah'tan gelen bir bilgiye dayandırmaktadır.

Nesefî̀nin "هو الله تعالى الواحد القيم" ifadesi hakkında yaptığı açı-

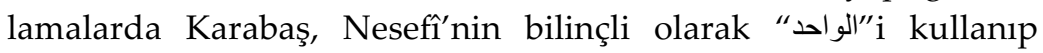
"الأحد"1 in sıfatları dişarıda bırakıp sadece zatı ifade ettiğini; "الواحد"in ise zatla birlikte sıfatları da içeren bir kullanıma sahip olduğunu vurgulayarak şerhini etimolojik açıklamalarla da zenginleştirmektedir. ${ }^{55}$

Karabaş, ru'yetullah hakkında, Nesefî'nin açıklamalarında dünyaya yönelik herhangi bir işaret olmasa da, bir keyfiyet ve cihet söz konusu olmaksızın, Allah'ın basiret ile dünyada görülmesini caiz olduğunu ileri sürmektedir. Ancak bu görmenin sahv değil mahv haline ${ }^{56}$ has olduğuna özellikle vurgu yapmaktadır. Şerhte

\footnotetext{
${ }^{54}$ Karabaş Veli, Şerhu akâidi'n-Nesefi bi lisâni't-tahkîk, İstanbul Büyükşehir Belediyesi, OE_Yz_0476, vr. 3/a-3/b; OE_Yz_1189, vr. 3/b-4/a; OE_Yz_1531, vr. 3/a

${ }^{55}$ Karabaş Veli, Şerhu akâidi'n-Nesefi bi lisâni't-tahkîk, İstanbul Büyükşehir Belediyesi, OE_Yz_0476, vr. 10/a; OE_Yz_1189, vr. 13/b-14/a; OE_Yz_1531, vr. 9/a.

${ }^{56}$ Sahv, vâridin etkisiyle kendinden geçen sûfînin sekr halinin geçmesini ifade eden bir kavramdır. Bkz. Abdullah Kartal, "Sekr", DIA, c. XXXVI, ss. 334-335; Bazı ayet ve hadislerde geçen mahv kavramı ise sûfî literatürde "seçkin kişilerin davranışlarını kendilerinden görmemesini", "kötü huyların terki", "iradesinden styrilıp Hakk'ın iradesine teslim olması" vb. anlamlara sahiptir. Bkz. Süleyman Uludağ, "Mahv ve İsbat", DİA, c. XXVII, ss. 395-396; Sûfîlerin mahv ve sahv hallerinde söyledikleri bazı ifadeler hakkında bkz. İbnu'l-Arabî, Fusûsu'l-Hikem (Tercüme ve Şerhi), c. III, s. 167.
} 
dikkat çeken en önemli hususlardan biri de Allah'ın insanı kendi suretinde yaratması hakkındaki açıklamasıdır. Allah öncelikle insanı iman ve küfrü tercih edebilecek bir uygunlukta yaratmıştır. Kendi suretinde yaratmasindan kastedilen ise, hayat, kudret, ilim, sem', basar, irade, tekellüm gibi sıfatlara sahip bir şekilde yaratmasidir. 57

\section{Değerlendirme}

Osmanlı Devleti'nin sosyo-politik açıdan oldukça hareketli olduğu ve Kadızadeliler-Sivâsiler şeklinde devlet ve topluma yayılmış bir tartışmanın yaşandı̆̆ı dönemde yaşayan Karabaş, Niyazi Mısrî gibi dönemin önemli sûfîlerinden biridir. Telif ettiği eserler de dikkate alındığında vahdet-i vücûd felsefesinin önemli temsilcilerinden biri olduğu rahatlıkla söylenebilir. Medrese eğitimi de alan Karabaş, mevcut iki geleneği birleştirdiği bir eser olarak Nesefî'nin akâidi'ni şerh etmiştir. Şerhin telif, beyan ve üslubunu belirleyen sebebin, Karabaş'ın kendi ifadelerinden de anlaşıldığı üzere, sûfîlerin Ehl-i Sünnet olmadıkları şeklindeki iddialar olduğu açıktır. Karabaş böyle bir psikoloji içerisinde sûfî literatürün remz ve işaret kavramlarını da kullanıp kendisine epistemolojik bir zemin oluşturmuştur. Hatta Nesefî'nin ifadelerinde sûfî itikadına dair remz ve işaret bulduğunu söylemesi, şerhin tasavvuf felsefesi içerisinde icra edileceğini açıkça göstermektedir.

Karabaş remz ve işareti öne çıkarsa da, onun yorumlarında dönemin olaylarının, oldukça belirleyici olduğu söylenebilir. Bununla birlikte Nesefî́nin eserinin tercih edilmesinin altında da bu sosyal ve psikolojik durumların etkisinin olduğu görülür. Zira şerhin gel-

\footnotetext{
${ }^{57}$ Karabaş Veli, Şerhu akâidi'n-Nesefi bi lisâni't-tahkîk, İstanbul Büyükşehir Belediyesi Osman Ergin Yazmaları, OE_Yz_0476, vr. 14/a-14/b; OE_Yz_1189, vr. 19/a19/b; OE_Yz_1531, vr. 12/a-13/a. İbn Arabî'nin konuyla ilgili yaklaşımları için bkz. Muhyiddin İbnü'l-Arabî, el-Futuhâtu'l-Mekkiyye, Daru'l-Kütübü'l-İlmiyye, Beyrut 1420/1999, c. I, ss. 156-158; Kurtubî de bu yorumu İbn Arabî'ye atfetmektedir. Muhammed b. Ahmed el-Ensârî el-Kurtubî, el-Cami' li ahkâmi'l-Kur'ân, thk: Ahmed Abdulalim, Dâru'ş-Şa'b, Kahire 1372, c. XX, ss. 114; İbrahim Coşkun, "Muhyiddin İbn Arabi'nin Felsefesinde "Allah" Mefhumu", Tasavvuf: İlmi ve Akademik Araştırma Dergisi (İbnü'l-Arabî Özel Sayısı), Yıl: 9 (2008), sayı: 21, s. 123; Şaban Çiftci, "Allah Âdem'i Kendi Sûretinde Yaratmıştır” Hadisinin Tahric ve Değerlendirmesi", Pamukkale Üniversitesi İlahiyat Fakültesi Dergisi, yıl: 2014/1, sayı: 1, s. 13 .
} 
diği nokta, Nesefî'nin metninin vahdet-i vücûd ekseninde bir tasavvuf felsefesini ihtiva ettiğidir. Bu noktanın remz ve işaretten önce taşıdığı anlam, sûfîlerin de aslında Ehl-i Sünnet hatta Ehl-i Sünnet'in gerçekte sûfîler olduğu iddiasını dile getirmesidir. Şerhin taşıdığ1 muhtemel ve bizce daha da önemli hususlardan biri, Osmanlı' da en yaygin metinlerden biri olarak Mâtüridî kelam geleneğine ait bir eserin Kadızâdeliler ve Sivâsîler çekişmesinde ortak otorite kabul edilmesidir. Diğeri ise şerhin bir sûfî tarafından yazılması, şartların kendileri açısından daha sıkıntılı olduğunu göstermektedir.

Karabaş'ın şerhi dikkatle incelendiğinde, Nesefî'nin varlık ve bilgi konusundaki yaklaşımlarının ve bunu dile getirdiği ifadelerin, kendisinden asırlar sonra yaşayan bir mutasavvıf tarafından, şerhin amacına matuf bir şekilde, sûfî itikadına dönüştürüldüğü, hatta Nesefî akâidi'nin sûfî itikadını remzler ve işaretlerle açılayan bir metin olarak sunulduğu görülmektedir. Karabaş'ın şerhi hakkında, asıl metnin bağlı bulunduğu kelâmî yapıdan uzaklaştırılıp varlık ve bilgi sorunlarını vahdet-i vücûd çerçevesinde ele alan bir hüviyete büründürüldüğü de söylenebilir.

Şerh hakkında bütüncül ve kapsayıı bir değerlendirme yapmak gerekirse bu değerlendirmenin birkaç açıdan olması muhtemeldir. Öncelikle şerh geleneği açısından oldukça özgün bir niteliğine sahip olduğu değerlendirmesini yapmamız kaçınılmazdır. Salt tekrar olma hüviyetine sahip olan şerhler bir vakıa olsa da, şerhin asıl metnin dönüşüm, değişim ve derinleştirilmesi adına bir inşa faaliyeti olma özelliği de dikkate alındığında, Karabaş'ın şerhinin önemli ve özgün bir şerh olduğunu söylemek mümkündür. Çünkü tevarüs edilen geleneklerin (kelam ve tasavvuf) birikimi üzerinden tekrar okunması neticesinde klasik bir metnin anlam küresinde (kelam metninde) şerh ile önemli bir derinliğe (tasavvufi boyuta) ulaşılmıştır.

Şerhin kendi içinde taşıdığı veya metinle birlikte değerlendirildiğinde taşıdığı anlamlar üzerinde farklı değerlendirmeler yapmak mümkündür. Buna göre şerhin kendi iç tutarlığı açısından düşünüldüğünde, şerhin amacına matuf kavramsal, epistemolojik ve ontolojik açıdan bir bütünlük taşıdığı ifade edilebilir. Metin ile birlikte düşünüldüğünde ise, şerhin doğasına uygun olarak, metnin dönüştürüldüğü ve değiş̧tirildiği kendini gösteren önemli hususlardır. 
Şerh edebiyatında dikkat çeken en önemli hususlardan birinin ise metnin ya da yazarın "otoritesi" olduğu dikkate alındığında, ${ }^{58}$ metnin sahip olduğu bu otorite, onun ilmi ve sosyal anlamda kurucu ve belirleyici karakterini de belirlemektedir. Buna göre şerh edilecek eserin otoritesi, kendisini, eserin ve müellifinin toplumsal ve ilmi hafızasında edindiği konumda ortaya koymaktadır. Karabaş'in şerhi, Nesefî akâidinin otoritesine dayanmakla birlikte bu durum oldukça farklı şekilde kendini göstermektedir. Şerhin kelam ve tasavvuf geleneklerinin varlık ve bilgi anlayışlarını birlikte içermesi, şerhin taşıdığı anlamı salt bir otoriteye dayanmaktan uzaklaştırmaktadır. Buna göre şârihin şerh için bir otorite tercihi salt bir tekrar ya da açıklama amacına matuf olmayıp yeni bir inşa süreci olarak değerlendirilebilir. Bu değerlendirmenin temel gerekçesi ise şerhin metni aşan yönünün, metni gölgede bırakmasıdır. Daha açık ifade ile şerh, bir otorite metin üzerinden tasavvuf geleneğinin belirli bir yaklaşım tarzını otorite olarak sunma eğilimi ve amacı taşımaktadır. Bu itibarla aslında şerh hakkında bir otoritenin yeni bir otorite inşası için yeniden telif etmeye dönük olduğu rahatlıkla ifade edilebilir. Zira Karabaş'in salt bir "akâidü's-sûfí" şeklinde bir metin telif etmek yerine "Nesefî akâidi"ni şerh ederek "Nesefî akâidi"ni "akâidü'ssûfi" ye dönüştüme çabası, salt bir telif, şerh ya da açılama olarak değerlendirilemez. Bu çaba, hakim bir paradigmanın otoritesini kullanarak yeni bir otorite ve paradigma inşası anlamı taşımaktadır. Şârihin yöntemsel olarak ise hakim paradigmanın otoritesini göz ardı etmek yerine, dönüşümü ve değişimi sağlayabilme adına metni dikkate alarak sistematik hareket ettiği söylenebilir.

Şerh hakkında "Mâtüridî geleneğe aidiyeti ile birlikte büyük kelâm geleneğinin akâid sistemini izhar eden bir parçası olan asıl metnin, vahdeti vücûd özelinde tasavouf felsefesinin temel kavramlarıla sûfî akâidinin epistemolojik ve ontolojik karakterlerini yansıtan bir metne dönüştürüldüğ̈̈" şeklinde toparlayıcı bir ifade serdetmek de mümkündür. Başka bir ifadeyle şerhin kabuğunu (metnin kavramlarının) kelâm metafiziği oluştursa da kabuğun içini (şerh) tasavvufî geleneğin epistemolojisi ve ontolojisi belirlemektedir. Bu ise metinsel otorite

\footnotetext{
${ }^{58}$ Nesefî'nin akâid metninin et-Taftâzânî, Ebû Hanîfe'nin el-Alîm ve'l-müteallim $a d l ı$ eserinin Eş'arî geleneğin önemli ismi İbn Fûrek ve yine Ebû Hanîfe'nin $e l$ Vasiyyesi'nin el-Bâbertî tarafından şerh edilmeleri; İbn Sînâ'nın el-İ̧sârâtı'na yapılan muhtelif şerhler ve et-Tahavî'nin akâid risâlesine yapılan çeşitli şerhler dikkate alındığında bu husus daha belirgin hale gelebilmektedir.
} 
anlamında kendi içinde farklı şekillerde yorumlanabilir. Asıl metnin otoritesi toplumsal alanda etkili olduğundan Nesefî akâidi Sünni kimliğin beyanı için bir dayanak kılınmış; daha sonra ise asıl metnin otoritesine boyun eğmek yerine, metni dönüştürüp sûfî itikadının temel metni haline getirilerek yeni bir telif olarak sunulmuştur.

\section{Kaynakça}

Abdülhamid, İrfan, İslam'da İtikadi Mezhepler ve Akaid Esasları, çev.: Mustafa Saim Yeprem, Türkiye Diyanet Vakfı Yay., Ankara 2011.

el-Afîfî, Ebu'l-Alâ, “Mu'tezile'nin Ma'dum Nazariyesi ile İbn Arabî'nin A'yân-1 Sabite Nazariyesinin Karşılaştırılması", çev. Cağfer Karadaş, Uludă̆ Üniversitesi İlahiyat Fakültesi Dergisi, yıl: 1997, c. 6, sayı: 6, ss. 267-276.

Arslan, Ahmet, İlkçă̆ Felsefe Tarihi 4 : Helenistik Dönem Felsefesi: Epikurosçular Stoacılar Septikler, İstanbul Bilgi Üniversitesi Yay., 2. Bsk., İstanbul 2010.

Bilmen, Ömer Nasuhi, Muvazzah İlmi Kelam, Bilmen Yayınevi, İstanbul 1972.

Coşkun, İbrahim, "Muhyiddin İbn Arabi'nin Felsefesinde "Allah" Mefhumu", Tasavvuf: İlmi ve Akademik Araştırma Dergisi (İbnü'l-Arab̂̂ Özel Sayısı), Yıl: 9 (2008), sayı: 21, ss. 117-143.

Çelebi, Kâtip, Mîzânü'l-hak fî ihtiyâri'l-ahak, Haz: Orhan Şaik Gökyay, MEB Yay., İstanbul 1993.

Çiftci, Şaban, "Allah Âdem'i Kendi Sûretinde Yaratmıştır" Hadisinin Tahric ve Değerlendirmesi", Pamukkale Üniversitesi İlahiyat Fakültesi Dergisi, yıl: 2014/1, sayı: 1, s. 13, ss. 1-20.

Demir, Hilmi, Delil ve İstidlâlin Mantık̂̂ Yapısı - İlk Dönem Sünni Kelam Örneği, Türkiye Diyanet Vakfı İslâm Araştırmaları Merkezi (İSAM) Yay., İstanbul 2012.

Demirli, Ekrem, “Zâhiri İlimlerin Otoritesi Karşısında Tasavvuf'un Meşruiyet Arayışı", İstanbul Üniversitesi İlahiyat Fakültesi Dergisi, sayı: 15, ss. 219-245.

Dinç, Abdullah, “Beyânu'l-Mezâhib Adlı Eseri Bağlamında Ömer Nesefi'nin Mezhepleri Tasnifi", Yayınlanmamış Yüksek Lisans Tezi, Kahramanmaraş Sütçü İmam Üniversitesi Sosyal Bilimler Enstitüsü, Kahramanmaraş 2012.

Düzgün, Şaban Ali, Nesefî ve İslam Filozoflarına Göre Allah Alem İlişkisi, Akçă̆ Yay., 1. Bsk., Ankara 1998.

Evkuran, Mehmet, Sünni Paradigmayı Anlamak - Bir Ekolün Politik ve Teolojik Yapılanması, Ankara Okulu Yay., Ankara 2016. 

Ahlak Hakikat ve Kimlik-İslam Kelamında Ahlak Problemi-, Araştırma Yay., 1. Bsk., Ankara 2013.

Fahri, Macit, İslam Felsefesi Tarihi, çev.: Kasım Turhan, Şa-to Yay., İstanbul 2008.

Gardet-Anawati, Louis ve Georges, İslam Teolojisine Giriş: Karşılaştırmalı Teoloji Denemesi, çev.: Ahmet Arslan, Ayrıntı Yay., İstanbul 2015.

Gökberk, Macit, Felsefe Tarihi, Remzi Kitabevi, 5. Bsk., İstanbul 1985.

Haksever, Ahmet Cahid, Çorum Tarihi ve Kültüründe Tasavvuf Geleneği, Çorum Belediyesi Kültür Yay., Çorum 2009.

İbnu'l-Arabî, Muhyiddin, Fusûsu'l-Hikem (Tercüme ve Şerhi), trc. Şrh.: Ahmed Avni Konuk, haz.: Mustafa Tahranlı - Selçuk Eraydın, Marmara Üniversitesi İlahiyat Fakültesi Yay., 6. Bsk., İstanbul 2014.

el-Futuhâtu'l-Mekkiyye, Daru'l-Kütübü'l-İlmiyye, Beyrut 1420/1999.

İbn Abdürrabih, İkdü'l-ferîd, nşr.: Ahmed Emin vd., Lecnetü't-Te'lif ve'tTerceme, Kahire 1389/1969.

Kara, İsmail, İlim Bilmez Tarih Hatırlamaz- Şerh ve Haşiye Meselesine Dair Birkaç Not, Dergah Yay., 2. Bsk., İstanbul 2013.

Kara, Kerim, "Karabaş Velî Hayatı - Eserleri ve Fikirleri”, Marmara Üniversitesi Sosyal Bilimler Enstitüsü, Doktora Tezi, İstanbul 2002.

"Karabaş Veli", DIA, yıl: 2001, c. XXIV.

Karabaş Veli, Ali Alaeddin Atvel b. Mehmed, Şerhu akâidi'n-Nesefi bi lisâni'ttahkîk, İstanbul Büyükşehir Belediyesi Osman Ergin Yazmaları, OE_Yz_0476, vr. 25.

Şerhu akâidi'n-Nesefi bi lisâni't-tahkîk, İstanbul Büyükşehir Belediyesi Osman Ergin Yazmaları, OE_Yz_1189, vr. 36.

Şerhu akâidi'n-Nesefi bi lisâni't-tahkîk, İstanbul Büyükşehir Belediyesi Osman Ergin Yazmaları, OE_Yz_1531, vr. 21.

Şerhu Akâidi'n-Nesefí, Bursa İnebey Yazma Eser Ktp., Orhan Camii Koleksiyonu, nr. 16 Or 613/2, vr. 100b-120a.

Şerhü Akâidin-Nesefîye, Ankara Milli Ktp., Ankara Adnan Ötüken İl Halk Kütüphanesi Kol., Nr. 1408, vr. 76.

Karadaş, Cağfer, "Kelamcıların İbn Arabî Düşüncesine Etkisi”, Uludağ Üniversitesi İlahiyat Fakültesi Dergisi, y1l: 2002, sayı: 2, c. 12, ss. 87-96.

Kartal, Abdullah, “Sekr", DIA, c. XXXVI, ss. 334-335.

Keskin, Fatih, "Ali el-Atvel Karabaş Velî ve Rislâletü'd-Deverân'1", Selçuk Üniversitesi Sosyal Bilimler Enstitüsü, (Yayınlanmamış Yüksek Lisans Tezi), Konya 2004.

Kılıç, Mahmut Erol, “Muhyiddin İbnu'l-Arabi'de Varlık ve Mertebeleri: Vücud ve Meratibu'l-vücud", Marmara Üniversitesi Sosyal Bilimler Enstitüsü, Doktora Tezi, İstanbul 1995. 
İbnü'l-Arabî, İSAM Yay., 1. Bsk, İstanbul 2015.

Koca, Ferhat, “Birleşen ve Ayrışan Yönleriyle Usûl-i Fıkhın Kelâm, Tasavvuf ve İslâm Felsefesi İle Olan İlişkisi", İslâmî İlimlerde MetodolojiVI ,İslâm Düşüncesinin Kurucu Unsurlart: Usûl-i Fıkıh, Kelâm, Tasavvufve İslâm Felsefesi, / Editörler: İlyas Çelebi, Mehmet Bulgen, 1. Bs. İstanbul: Ensar Neşriyat, 2016, ss. 201-315.

“Osmanlılar Dönemi Fıkıh-Tasavvuf İlişkisi: Fakılar ile Sofular Mücadelesinin Tarihi Serüveni", Gazi Üniversitesi Çorum İlahiyat Fakültesi Dergisi, 2002/1, cilt: I, sayı: 1, ss. 73-131.

Kurnaz- Tatcı, Cemal -Mustafa, “Karabaş-1 Velî (ö. 1097/1686)”, Tasavvuf İlmi ve Akademik Araştırmalar Dergisi, sy. 6, Ankara 2001.

el-Kurtubî, Muhammed b. Ahmed el-Ensârî, el-Cami' li ahkâmi'l-Kur'ân, thk: Ahmed Abdulalim, Dâru'ş-Şa'b, Kahire 1372, c. I-XX.

el-Mâtürîdî, Ebû Mansûr Muhammed b. Muhammed es-Semerkandî, Kitâbu't-Tevhîd, thk: Bekir Topaloğlu-Muhammed Aruçi, Dâr-u Sâdr-Mektebetü'l-İrşâd, 2. Bsk., Beyrut 2010.

el-Ma'nevî, Mustafa, Terceme-i Şerhi'l-Akaidi'l-Nesefiyye, Süleymaniye Ktp., Hacı Mahmud Efendi Kol., nr. 1303, vr. 58. Cevâhiru'l-Akâid, Süleymaniye Ktp., Hacı Mahmud Efendi Kol., nr. 1393, vr. 58. Cevâhiru'l-Akâid, Konya Bölge Yazma Eser Ktp., Burdur İl Halk Kütüphanesi Kol., nr. 826/2, vr. 42b-88a.

en-Nesefî, Ebu'l-Muîn Meymûn b. Muhammed, Tabsıratü'l-edille fî usûli'ddîn, thk: Hüseyin Atay, Diyanet İşleri Başkanlığı Yay., Ankara 1993.

Pezdevî, Usûli'd-Dîn (Ehl-i Sünnet Akâidi), çev: Şerafeddin Gölcük, Kayıhan Yay., İstanbul 20.

es-Sâbûnî, Nûreddîn, el-Bidâye fì usûli'd-dîn (Mâtürîdiyye Akâidi), Çev: Bekir Topaloğlu, Diyanet İşleri Başkanlığı Yay., 8. Baskı, Ankara 2005.

es-Saffâr el-Buhârî, Ebû İshâk İbrahim b. İsmâîl b. Ahmed b. İshâk, Telhîsu'ledille li kavâidi't-tevhid, thk: Hişam İbrahim Mahmud, Dâru'sSelâm, 1. Bsk., Kâhire 2010/1431.

Sunar, Cavit, Varlık Hakkında Ana Düşünceler, Ankara Üniversitesi İlahiyat Fakültesi Yay., Ankara 1977.

eş-Şâfiî, Hasan Mahmûd, Kelam'a Giriş, çev.: Süleyman Akkuş, Değişim Yay., İstanbul 2009.

Şimşek, Halil İbrahim “İsmail Fenni Ertuğrul’un İbnü'l-Arabî ve Vahdet-i Vücud Savunması", Tasavvuf: Ilmi ve Akademik Araştırmalar Dergisi (İbnü'l-Arabî Özel Sayısı), yıl: 9 (2008), sayı: 21, s. 199-212.

Taftazânî, Kelam İlmi ve İslâm Akâidi (Şerhu'l-Akâid), Haz.: Süleyman Uludağ, Dergah Yay., 5. Bsk., İstanbul 2010. 
Şerh ve Otorite İlișkisi: XVII. Yüzyıla Ait Bir Şerhin Analizi

Uludağ, Süleyman, “A'yân-1 Sâbite”, DIA, İstanbul, Y1l: 1991, c. IV. "Mahv ve İsbat", DİA, c. XXVII, ss. 395-396.

Yavuz, Yusuf Şevki, “Akâidu'n-Nesefî”, DİA, yıl: 1989, c. II, ss. 217-219.

Yetkin, Safvet Kemalüddin, "Kelamdan Tasavvufa", Ankara Üniversitesi İlahiyat Fakültesi Dergisi, yıl: 1953, c. II, sy: 4, ss. 1-21. 